\title{
Special Properties of Polycentric Anaerobic Fungus Anaeromyces mucronatus
}

\author{
K. FLIEGEROVÁ ${ }^{1}$, S. PAŽOUTOVÁ ${ }^{2}$, J. MRÁZEK $^{1}$, J. KOPEČNÝ ${ }^{1}$ \\ ${ }^{1}$ Institute of Animal Physiology and Genetics, Czech Academy of Sciences, Prague, Czech Republic \\ ${ }^{2}$ Institute of Microbiology, Czech Academy of Sciences, Prague, Czech Republic
}

Received July 22, 2002

Accepted November 18, 2002

\begin{abstract}
Fliegerová K., S. Pažoutová, J. Mrázek, J. Kopečný: Special Properties of Polycentric Anaerobic Fungus Anaeromyces mucronatus. Acta Vet. Brno 2002, 71: 441-444.

The aim of this study was differentiation of polycentric rumen fungus of genera Anaeromyces using modern methods of molecular biology. Six polycentric anaerobic fungi isolated from cow, lama and bison were identified as Anaeromyces strains and analyzed for variability in internal transcribed spacers and fibrolytic activities. RFLP of both ITS1 and ITS1-4 fragments digested by restriction enzyme DraI separated studied strains into two groups with different cleavage profiles. Representatives of each group exhibited different hydrolytic enzyme activities. The largest differences were recorded in production of xylanase, $\beta$-endoglucanase and $\beta$-glucosidase. The possibility of using RFLP analysis of ITS regions to distinguish fungal isolates has been proved, however the results do not illuminate what kind of distinction is reflected in genetic variability of ITS regions.
\end{abstract}

Rumen, fungi, anaerobic, cellulose, fiber, endoglucanase

Anaeromyces mucronatus was originally described from a Holstein cow in France (Breton et al. 1990) as the third polycentric anaerobic rumen fungal species besides Orpinomyces and Ruminomyces genera. However, Ruminomyces elegans has been reassigned to Anaeromyces elegans in 1993 (Ho et al. 1990, 1993).The morphological differences among polycentric genera Orpinomyces and Anaeromyces are minimal and may vary under different culture conditions. Moreover, these species tend to lose their ability to produce sporangia in artificial media and therefore pure culture cannot be identified with absolute certainty (B arr et al. 1995).

The development of molecular biological techniques in the last decade has enabled the new approach to the characterization of fungi. Li and Heath (1992) studied relationship of gut fungi based on ITS1 sequences and found that Anaeromyces isolates were more distant from other rumen fungi. The whole DNA sequences showed above $80 \%$ similarity among Piromyces, Neocallimastix and Orpinomyces, whereas the similarities between Anaeromyces and these three genera were only $70 \%$.

Despite the fact that fibrolytic enzymes of anaerobic rumen fungi have been studied intensively, there are no available data describing Anaeromyces cellulolytic and xylanolytic activities.

The aim of our experiment was to determine the feasibility of using RFLP analysis of ITS fragment to distinguish among species rumen fungi assigned to Anaeromyces genera. In this paper six Anaeromyces strains isolated from different animals were studied using RFLP analysis of ITS1 and ITS 1-4 spacer. We present here also for the fist time endoglucanase and xylanase activities of Anaeromyces isolates.

\section{Materials and Methods}

Organisms and culture conditions

Polycentric anaerobic fungi were isolated by the method of Joblin (1981) from faeces of domestic ruminants

Address for correspondence:

RNDr. K. Fliegerová, CSc.

Institute of Animal Physiology and Genetics

Czech Republic
Phone: +420267090506

Fax: +420267090500

@iapg.cas.cz 
and herbivores kept in the Prague ZOO. Strain K1 originates from cow, strains LG1 and LG2 from Lama guanaco, strains $\mathrm{Zu} 1$ and $\mathrm{Zu} 2$ from European bison, strain Alp2 originates from Lama alpaca. Strains with the same sign ( $\mathrm{LG}$ or $\mathrm{Zu}$ ) but different number were isolated from the same animals with the lapse of time. Fungi were maintained anaerobically at $39^{\circ} \mathrm{C}$ on the medium M10 (Cald well and Bryant 1966) enriched by $20 \%$ (v/v) of rumen fluid. Glucose $(4 \mathrm{~g} / \mathrm{l})$, cellobiose $(4 \mathrm{~g} / \mathrm{l})$ or microcrystalline cellulose $(4 \mathrm{~g} / \mathrm{l})$ was used as a carbon source. Subculturing of isolates was performed every three days to maintain fungal viability.

Morphological observations and metabolic study

In-two-day cultures, thalli were observed by fluorescence microscopy (Fluoval 2, Carl Zeiss, Jena, F.R.G) using bisbenzimidin $(5 \mathrm{mg} / \mathrm{l})$ as staining solution. Nuclei fluorescence was examined using transmitted-light microscope fitted with an exciter filter (G 355) and barrier filter (465) as described by Gaillard et al. (1989).

End fermentation products were determined by gas chromatography using column Chromosorb WAW (200 mm, $3 \mathrm{~mm}$ ID) and FID detector.

Enzyme assays

Activities of xylanase and $\beta$-endoglucanase (CM-cellulase) were measured in the course of reducing sugars release from soluble xylan extracted from oat spelts and carboxymethylcellulose according to the method of Lever (1977). Substrates for an estimation of cellobiohydrolase, $\beta$-xylosidase and $\beta$-glucosidase activity were 4-nitrophenyl- $\beta$-D-cellobioside, 4-nitrophenyl- $\beta$-D-xylopyranoside and 4-nitrophenyl- $\beta$-D-glucopyranoside (Hodrová et al. 1999)

DNA isolation, PCR and RFLP of ITS fragment

Fungal genomic DNA was extracted using the method of Graham et al. (1994), resuspended in distilled water and stored at $-35^{\circ} \mathrm{C}$. ITS 1 region was amplified from genomic DNA by PCR using primers ITS 1 (5 - TCC GTA GGT GAA CCT GCG G-3`) and ITS 2 (5`- GCT GCG TTC TTC ATC GAT GC-3`), ITS 1-4 region was amplified with primers ITS 1 and ITS 4 ( $5^{`}$ - TCC TCC GCT TAT TGA TAT GC - $3^{`}$ ). The PCR reaction was performed using kit Readymix ${ }^{\mathrm{TM}}$ Redtaq $^{\mathrm{TM}}$ PCR reaction mix (Sigma, U.S.A). Approximately $50 \mathrm{ng}$ genomic DNA were used as template for each amplification. The temperature conditions were as follows: initial denaturation at $94^{\circ} \mathrm{C}$ for $4 \mathrm{~min}$, followed by 35 cycles of denaturation at $94{ }^{\circ} \mathrm{C}$ for $30 \mathrm{~s}$, annealing at $42^{\circ} \mathrm{C}$ for $30 \mathrm{~s}$ and extension at $72{ }^{\circ} \mathrm{C}$ for $1 \mathrm{~min}$. Final step was carried out at $72^{\circ} \mathrm{C}$ for $5 \mathrm{~min}$.

The PCR products were digested with enzyme $\operatorname{DraI}\left(\right.$ at $37^{\circ} \mathrm{C}$ for $2 \mathrm{~h}$ ) and restriction fragments were resolved in TBE buffer on $3 \%$ agarose gel with ethidium bromide at $40 \mathrm{~V}$ for $4 \mathrm{~h}$. The pUC18 MspI Digest (Sigma, U.S.A) ladder was used as molecular weight standard.

\section{Results and Discussion}

\section{Characterization of isolates}

All six strains K1, LG1, LG2, Zu1, Zu2 and Alp2 observed by fluorescence microscopy after staining with bisbenzimide exhibited extensive highly branched thallus (Plate I, Fig. 1) and large hyphae with constrictions (Fig. 2) typical for Anaeromyces genera. Both figures show multinucleate filamentous rhizomycelium with exogenous development of sporangia. The production of zoospores has not been observed in this study.

No differences among studied strains were measured in production of volatile fatty acids. All six strains had similar mixed-acid fermentation profiles where acetate was the main end product regardless of utilized substrates (glucose, cellobiose or cellulose).

Restriction polymorphism of the intergenic regions

Digestion of the ITS fragments by restriction endonuclease could distinguish among studied Anaeromyces isolates. Fig. 3 (Plate II) shows that splitting of ITS1 as well as ITS14 spacers by enzyme DraI produced the same cleavage profiles for strains Zu1, LG1 and K1 different from restriction pattern of strains $\mathrm{Zu} 2, \mathrm{LG} 2$ and Alp2. The approximate length of ITS restriction fragments is summarized in Table 1. These results demonstrate that PCRgenerated RFLP analysis of the intergenic rDNA region is a reliable technique to distinguish among isolates of rumen fungi of the same genera, however our results do not answer a question which differences these analysis reflect. Study of larger number of strains belonging to Anaeromyces genera of different geographical origin is necessary to succeed to solve this problem. 
Table 1

RFLP profiles resulting from DraI digestion of ITS fragments

\begin{tabular}{|l|c|c|c|c|}
\hline & \multicolumn{2}{|c|}{ ITS 1 } & \multicolumn{2}{c|}{ ITS 1-4 } \\
\hline Strains & LG1, Zu1, K1 & LG2, Zu2, Alp2 & LG1, Zu1, K1 & LG2, Zu2, Alp2 \\
\hline Band sizes (bp) & $175,62,30$ & $105,62,50,30$ & $237,188,108,80$ & $230,102,63,40$ \\
\hline
\end{tabular}

Fibrolytic activities

Selected isolates were tested for their fibrolytic activities (Table 2). Representative of first group was isolate Zu1 and from the second group were chosen isolates Alp2 and LG2. Second group was characterized by high $\beta$-endoglucanase, xylanase and $\beta$-glucosidase activity while isolate $\mathrm{Zu} 1$ showed higher activities of cellobiohydrolase and $\beta$-xylosidase. Obtained results contribute to enzyme characterization of polycentric anaerobic fungi reported by Ho et al. (1994) and open a scope for reflection of probability that both groups of Anaeromyces isolates have different strategy for fiber degradation. The first group is focused on oligosaccharides and the second one on plant structural polysaccharides. Both groups can cooperate in fiber degradation in the rumen environment.

Table 2

Hydrolytic activities of Anaeomyces isolates. Fungi were clustered to groups according to their genetic properties.

\begin{tabular}{|c|c|c|c|}
\hline \multicolumn{2}{|r|}{ Group1 } & \multicolumn{2}{|c|}{ Group2 } \\
\hline & $\mathrm{Zu} 1$ & Alp2 & LG2 \\
\hline \multicolumn{4}{|c|}{$\mu \mathrm{g}$ saccharide $\cdot \mathrm{ml}^{-1} \cdot \mathrm{h}^{-1}$} \\
\hline$\beta$-endoglucanase & $32.6 \pm 1.2$ & $124.5 \pm 4.5$ & $286.0 \pm 6.9$ \\
\hline Xylanase & $37.0 \pm 2.2$ & $166.3 \pm 4.8$ & $237.4 \pm 3.7$ \\
\hline Cellobiohydolase & $29.6 \pm 0.9$ & $6.8 \pm 0.8$ & $14.9 \pm 1.1$ \\
\hline$\beta$-glucosidase & $1.0 \pm 0.6$ & $140.7 \pm 4.6$ & $107.4 \pm 6.2$ \\
\hline$\beta$-xylosidase & $135.1 \pm 5.1$ & $80.9 \pm 3.3$ & $88.0 \pm 2.5$ \\
\hline
\end{tabular}

\section{Rozdílné vlastnosti izolátů polycentrické anaerobní houby Anaeromyces mucronatus}

Šest anaerobních polycentrických hub bylo izolováno z tráveniny krávy, lamy a bizona. Tyto izoláty byly identifikovány jako kmeny rodu Anaeromyces. U všech kmenů byla analyzována podobnost ITS (intergenic transcribed spacer) fragmentů a stanovena fibrolytická aktivita. Na základě RFLP (restriction fragment length polymorphism) ITS fragmentů štěpených restrikční endonukleasou Dra I byly testované kmeny rozděleny do dvou skupin. Zástupci obou skupin vykazovaly rozdílné aktivity hydrolytických enzymů. Největší rozdíly byly pozorovány v aktivitách xylanasy, $\beta$-endoglukanasy a $\beta$-glukosidasy. Bylo znovu prokázáno, že ITS fragmenty mohou být využity pro taxonomické účely a aspoň jedna skupina našich izolátů představuje nový druh anaerobní houby.

Acknowledgements

This work was supported by The Grant Agency of the Czech Republic (Project No. 523/96/0103).

\section{References}

BARR, DJS, YANKE, LJ, BAE, HD, McALLISTER, TA, CHENG, KJ, 1995: Contribution on the morphology and taxonomy of some rumen fungi from Canada. Mycotaxon LIV: 203-214

BRETON, A., BERNALIER, A., DUSSER, M., FONTY, G., GAILLARD-MARTINIE, B., GUILLOT, J. 1990: Anaeromyces mucronatus nov. gen. nov. sp. A strictly anaerobic rumen fungus with polycentric thallus. FEMS Microbiol Letters 70: 177-182

CALDWELL, DR, BRYANT, MP, 1966: Medium without rumen fluid for non-selective enumeration and isolation of rumen bacteria. Appl Microbiol 14: 794-801 
444

GAILLARD, B, BRETON, A, BERNALIER, A, 1989: Study of nuclear cycle of four species of strictly anaerobic rumen fungi by fluorescence microscopy. Cur Microbiol 19: 103-107

GRAHAM, GC, MAYERS, P, HENRY, RJ, 1994: A simplified method for the preparation of fungal genomic DNA for PCR and RAPD analysis. Bio Techniques 16: 48-50

HO, YW, KHOO, IYS, TAN, SG, ABDULAH, N, JALALUDIN, S, KUDO, H, 1994: Isoenzyme analysis of anaerobic rumen fungi and relationship to aerobic chytrids. Microbiol 140, 1495-1504

HO,YW, BAUCHOP,T, ABBULAH, N, JALALUDIN, S, 1990: Ruminomyces elegans gen. Et sp. nov. a polycentric anaerobic rumen fungus from cattle. Mycotaxon 38: 397-405

HO, YW, BARR, DJS, ABBULAH, N, JALALUDIN, S, KUDO, H, 1993: Anaeromyces, an earlier name for Ruminomyces. Mycotaxon 47: 283 - 293

HODROVÁ B, KOPEČNÝ J, KÁŠ J, 1998: Cellulolytic enzymes of rumen anaerobic fungi Orpinomyces joyonii and Caecomyces communis. Res Microbiol 149: 417-427

JOBLIN, KN, 1981: Isolation, enumeration and maintenance of rumen anaerobic fungi in roll tubes. Appl Environ Microbiol 42: (6) 1119-1122

LI, J, HEATH, JB, 1992: The phylogenetic relationship of the anaerobic chytridiomycetous gut fungi (Neocallimasticacea) and the Chytridiomycota. I. Cladistic analysis of rRNA sequences. Can J Bot 70: 17381746 
Plate I

Fliegerová K. et al.: Special Properties... pp. 441-444

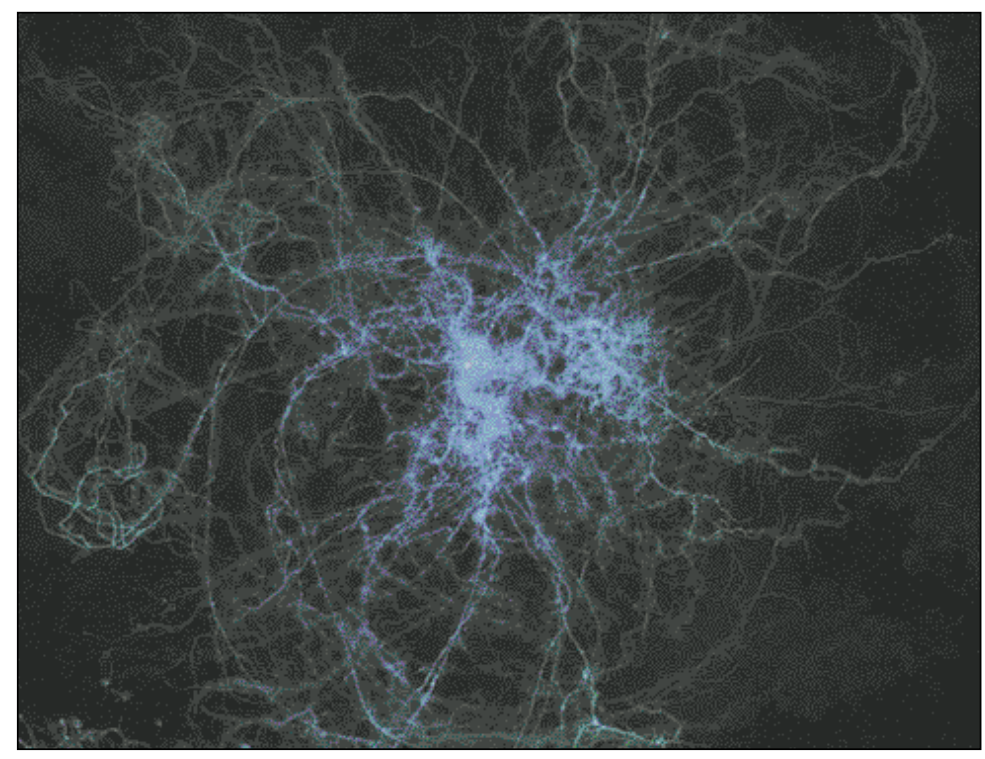

Fig. 1. Negative photograph of Anaeromyces sp., Zu1 branched mycelium. Nuclei were stained with bisbenzimidin.

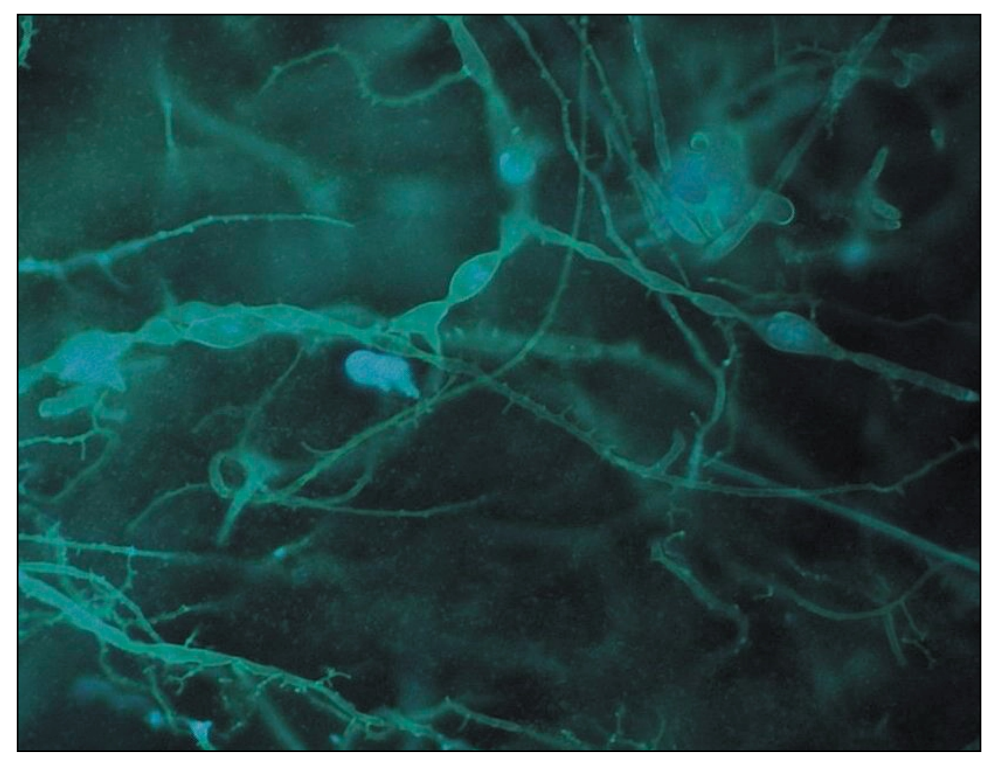

Fig. 2. Negative photograph of Anaeromyces sp., Zu2. mycelium with developed constrictions. 
Plate II

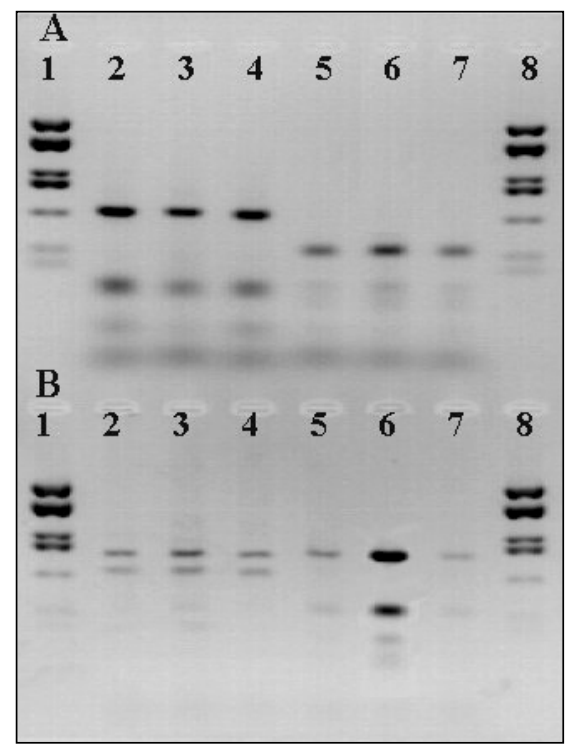

Fig. 3. Gel electrophoresis of ITS RFLP analysis. A - ITS 1, B -ITS 1-4; 2 - LG1, 3 - Zu1, 4 - K1, 5 - LG2, 6-Zu2, 7 - Alp2; 1 and 8 - DNA ladder (pUC18 MspI Digest contains the following visible fragments: 501, $489,404,353,242,190$ and $147 \mathrm{pb})$. 